\title{
Prognostic Factors In Breast Cancer Patients With Hepatic Metastases: Impact Of Molecular Subtype And Local Hepatic Treatment
}

\author{
Ozturk ATES ${ }^{1}$, Deniz Can GUVEN² ${ }^{2}$ Taner BABACAN ${ }^{1}$, Veli SUNAR ${ }^{1}$, Furkan SARICI ${ }^{1}$, \\ Sercan AKSOY ${ }^{1}$, Ali R SEVER ${ }^{3}$, Yavuz OZISIK $^{1}$, Kadri ALTUNDAG ${ }^{1}$
}

\author{
${ }^{1}$ Hacettepe University Cancer Institute, Department of Medical Oncology \\ ${ }^{2}$ Hacettepe University Faculty of Medicine, Department of Internal Medicine \\ ${ }^{3}$ Hacettepe University Faculty of Medicine, Department of Radiology, Ankara, TURKEY
}

\begin{abstract}
Liver metastases usually develop in the terminal stage of breast cancer (BC), and often accompany with extrahepatic metastases. The prognosis of hepatic metastases $(\mathrm{HM})$ in $\mathrm{BC}$ patient is poorer compared to bone and soft tissue metastases. In this study, we aimed to analyze some clinico-pathological prognostic factors in patients with HM. A total of 4300 follow-up records of breast cancer patients diagnosed and treated at Hacettepe University Cancer Institute between January 2000 and July 2015 were retrospectively analyzed. Total of $312 \mathrm{BC}$ patients with $\mathrm{HM}$ were enrolled to study. Patients with $\mathrm{HM}$ at diagnosis and the patients who developed metastases during the follow-up were included. Total of 50 (16\%) patients have HM as the first site of metastasis. While isolated HM were just seen in $36(11 \%)$ patients, most of the patients had hepatic as well as bone metastases ( $n=148,47 \%)$. Median interval from initial diagnosis to HM was 40.5 (5-262) months. Low grade (grade 1-2) tumors were associated with longer disease free interval to liver metastases by multivariate analysis. Overall survival after HM in whole group was 18 months. Multivariate analysis revealed statistically significant association between long survival and non-triple negative molecular subtype, lower stage disease at diagnosis and application of local hepatic treatment. Developments in systemic and targeted therapy, as well as local hepatic therapies may enhance outcomes of patient with hepatic metastases.
\end{abstract}

Keywords: Metastatic breast cancer,Hepatic metastases, Molecular subtypes, Local hepatic therapies

\section{ÖZET}

Karaciğer Metastazlı Meme Kanseri Hastalarında Prognostik Faktörler: Moleküler Alt Tip Ve Lokal Karaciğer Tedavisinin Etkisi

Karaciğer metastazları meme kanserinin (MK) genellikle son döneminde gelişir ve çoğunlukla olarak karaciğer dışı metastazlara eşlik eder. MK hastasındaki karaciğer metastazlarının (KM) prognozu, kemik ve yumuşak doku metastazlarına göre daha kötüdür. Bu çalışmada, KM'li hastalarda bazı klinikopatolojik prognostik faktörleri analiz etmeyi amaçladık. Ocak 2000- Temmuz 2015 tarihleri arasında Hacettepe Üniversitesi Kanser Enstitüsü'nde tanı konulup tedavi edilen 4300 meme kanseri hastalarının izlem kayıtları geriye dönük olarak analiz edildi. Karaciğer metastazlı toplam 312 hasta çalışmaya alındı. Tanıda KM olan ve takip sırasında karaciğer metastazı gelişen hastalar çalışmaya dahil edildi. Toplam 50 (\% 16) hastada ilk metastaz yeri karaciğerdi. İzole KM sadece 36 hastada (\% 11) görüldü, ancak hastaların çoğunda kemik metastazı ve karaciğer metastazı vardı ( $n=148, \%$ 47). Karaciğer metastazı illk tanıdan itibaren ortanca 40,5 (5-262) ayda gelişti. Çok değişkenli analiz ile yapılan değerlendirmede karaciğer metastazına kadar geçen zaman düşük dereceli (1-2 grade) tümörlerde daha uzun bulundu. Tüm grupta HM sonrası ortanca genel sağ kalım 18 aydı. Çok değişkenli analiz ile uzun yaşam; triple negatif dışı moleküler alt tip, tanıda düşük evre hastalık ve lokal karaciğer tedavi uygulaması arasında istatistiksel olarak anlamlı bir ilişki saptandı. Sistemik ve hedefe yönelik tedavideki gelişmelerin yanı sıra lokal hepatik terapiler, hepatik metastazlı hastaların sonuçlarıı daha da iyileştirebilir.

Anahtar kelimeler: Metastatic meme kanseri, Karaciğer metastazı, Moleküler subtip, Lokal karaciğer tedavileri 


\section{INTRODUCTION}

Breast cancer is starting mostly as a local disease; approximately $30 \%$ of all patients develop metastatic disease. ${ }^{1-2}$ The bone, lung and brain are the most common metastatic sites of breast cancer. Liver is an uncommon site of metastasis as a first locus of metastasis, observed in 6-25\% of patients with advanced breast cancer. ${ }^{3}$ Hepatic metastases (HM) are regarded as a poor prognostic factor; most authors reported a median survival of less than 12 months. ${ }^{4-6}$ This data comes from the former times studies when patients were often diagnosed at later stages that the liver failure symptoms might have already started. Due to the advanced imaging techniques and screening programs, the development of new target agents, and local hepatic interventions, the median survival of patients with HM was increased to $18-34$ months. ${ }^{7}$ Median survival was calculated as 27 and 15.2 months in patients who had isolated hepatic metastases and in patients with hepatic as well as disseminated disease respectively. ${ }^{8}$ This seems to be even further improving with new studies thanks to continuous advances in imaging modalities and effective salvage chemotherapy regimens. ${ }^{9}$ Also new markers are being evaluated for prognosis including molecular subtyping of breast cancer patients.

For these reasons, herein we present clinicopathological features and outcome data of one of the largest retrospective series to date to evaluate the prognostic factors in breast cancer patients with HM to aid in treatment choices and to improve the outcome of these patients.

\section{PATIENTS AND METHODS}

A total of 4300 follow-up records of breast cancer patients at Hacettepe University Cancer Institute between January 2000 and July 2015 were retrospectively analyzed. Three hundred and twelve breast cancer patients with liver metastases were included in the study. Patients with liver metastases at diagnosis and the patients who developed metastases during the follow-up were included. Demographical and clinicopathological characteristics including; age, gender, menopausal status, tumor histology, grade, TNM stage, hormonal receptor status, HER-2 receptor overexpression status, and overall survival were recorded. Breast cancers were classified into four molecular subtypes according to immunohistochemically panel as luminal A (ER and/or PgR positive and HER-2 negative), luminal B (ER and/or PgR positive and HER-2 positive), HER-2 overexpression (ER and PgR negative and HER-2 positive), and triple negative (TNBC). HM were diagnosed by using imaging techniques (liver ultrasound, computed tomography, magnetic resonance imaging and positron emission tomography) or by liver biopsy. If the patients had concomitant liver metastasis with extrahepatic metastases and they have the typical clinical signs of metastatic, patients are treated with radiological findings. In a situation that patient had only liver metastases and if there is suspicion of liver metastases, biopsy was done.

There were total of 105 patients with stage 1 and 2 at diagnosis. When these patients were evaluated premenopausal and postmenopausal patients were 60 and 42 respectively. Hormonotherapy was applied total of 76 patients (tamoxifen, $n=58$ or aromatase inhibitor, $\mathrm{n}=18$ ). Adjuvant radiotherapy was applied total of 62 patients. Also total of 90 patients were treated with adjuvant chemotherapy with drugs as; only anthracycline based $(n=50)$, anthracycline with paclitaxel based $(n=26)$. Stage 1-2 patients had followed including physical examination, laboratory test, ultrasound or tomography every 4-6 months and annually mammography after the first 1-2 years of adjuvant therapy. After then the patients were followed every 6 months up to 5 years.

Furthermore there were 99 patients with stage 3 . Hormonotherapy was applied 69 patients (tamoxifen $n=50$, aromatase inhibitor, $n=18$ ). Total of 94 patients received adjuvant radiotherapy. Adjuvant chemotherapy was applied total of 97 patients with drugs as; anthracycline with taxane based $(n=76)$, anthracycline based $(n=19)$. In locally advanced and metastatic patients had followed closely. Follow up of these patients included physical examination, radiological and laboratory test every 3 months for 1-2 year.

All data was analyzed by SPSS 18 (SPSS, Inc., Chicago, IL) software. Survival analysis was estimated using the Kaplan-Meier method using the log-rank test. P-value $<0.05$ was considered 
statistically significant. Univariate and multivariable Cox proportional hazards model was used to evaluate the influence of all potential predictive and prognostic factors on the survival measures. Hazard ratios (HRs) estimated from the Cox analysis were reported as relative risks with corresponding $95 \%$ confidence intervals (CIs). The Cox proportional hazards regression was implemented for multivariate analysis.

\section{RESULTS}

\section{Patient Characteristics}

A total of 312 breast cancer patients with hepatic metastases were analyzed. Characteristics of patients were shown in Table 1. All patients were women. Median age was 46 (min-max:18-83) years at diagnosis. Most of patients were premenopausal $(n=171,55 \%)$. The majority of cases were diagnosed with invasive ductal carcinoma (82.4\%). Most patients were diagnosed at stage 3 (32\%) and stage $4(31 \%)$ disease. Molecular subtypes were classified as follows; luminal A, 131 (42\%); luminal B, 84 (27\%); HER-2 overexpressed, 47 (15\%); TNBC, $41(13 \%)$ at diagnosis of breast cancer. Total of $50(16 \%)$ patients had liver metastasis as the first focus of metastasis. While isolated hepatic metastases were seen in $36(11 \%)$ patients, most of the patients had hepatic and bone metastases ( $\mathrm{n}=148,47 \%)$. Also hepatic as well as lung and brain metastases were seen in $73(23 \%)$ and 28 (9\%) patients respectively (Table 2). Higher proportion of luminal A and B was observed in patient with isolated hepatic metastases (36\% and 19\% respectively) However, this ratio was lower in patient with hepatic as well as brain metastasis (17\% and $11 \%$ ). Also Her-2 overexpression and TNBC ratio was higher in patient with hepatic with brain metastasis (43\% and 29\%).

\section{Time to Development of Hepatic Metastases}

Median follow up period of patients was 52 (3$177)$ months. Median interval from initial diagnosis to hepatic metastases was 40.5 (5-262) months. Univariate analysis has shown that the time to develop hepatic metastases was longer in stage 1-2 disease (vs. stage 3), low grade (grade 1-2) disease,

\begin{tabular}{|c|c|}
\hline Parameters & $\begin{array}{l}\text { Whole group } \\
\text { n (\%) }\end{array}$ \\
\hline Median age (range) & $46(18-83)$ \\
\hline \multicolumn{2}{|l|}{ Histology of primary tumor } \\
\hline Invasive ductal & 257 (82\%) \\
\hline Invasive lobular & $8(3 \%)$ \\
\hline Mixed & 29 (9\%) \\
\hline Other & $18(6 \%)$ \\
\hline \multicolumn{2}{|l|}{ Menopausal state at diagnosis } \\
\hline Premenopausal & $171(55 \%)$ \\
\hline Postmenopausal & $121(39 \%)$ \\
\hline Perimenopausal & $20(6 \%)$ \\
\hline \multicolumn{2}{|l|}{ TNM stage at diagnosis } \\
\hline Stage1 & $18(6 \%)$ \\
\hline Stage 2 & 87 (28\%) \\
\hline Stage 3 & 99 (32\%) \\
\hline Stage 4 & 98 (31\%) \\
\hline Unknown & $10(3 \%)$ \\
\hline \multicolumn{2}{|l|}{ Molecular Subtypes } \\
\hline Luminal A & $131(42 \%)$ \\
\hline Luminal B & 84 (27\%) \\
\hline HER-2 Positive & 47 (15\%) \\
\hline Triple Negative & $41(13 \%)$ \\
\hline Unknown & $9(3 \%)$ \\
\hline \multicolumn{2}{|l|}{ Adjuvant chemotherapy } \\
\hline Stage 1-2 & 90 (28\%) \\
\hline Anthracycline based & $50(16 \%)$ \\
\hline Anthracycline with paclitaxel based & $26(8 \%)$ \\
\hline Other & $14(4 \%)$ \\
\hline Stage 3 & 97 (31\%) \\
\hline Anthracycline based & 19 (6\%) \\
\hline Anthracycline with paclitaxel based & $76(24 \%)$ \\
\hline Other & $2(1 \%)$ \\
\hline \multicolumn{2}{|l|}{ Adjuvant radiotherapy } \\
\hline Stage 1-2 & 62 (20\%) \\
\hline Stage 3 & 94 (20\%) \\
\hline \multicolumn{2}{|l|}{ Adjuvant hormonotherapy } \\
\hline Stage 1-2 & 76 (24\%) \\
\hline Stage 3 & 69 (22\%) \\
\hline
\end{tabular}


Table 2. Features of patients with hepatic with/without other locations of metastatic disease $(n=312)$

\begin{tabular}{|c|c|c|c|c|}
\hline Parameters & $\begin{array}{l}\text { Hepatic with bone } \\
n=148(47 \%)\end{array}$ & $\begin{array}{l}\text { Hepatic with lung } \\
72(23 \%)\end{array}$ & $\begin{array}{l}\text { Hepatic with brain } \\
28(9 \%)\end{array}$ & $\begin{array}{l}\text { Soliter hepatic } \\
36(11 \%)\end{array}$ \\
\hline Median age (range) & $46(18-78)$ & $45(28-83)$ & $48(26-76)$ & $46(18-68)$ \\
\hline \multicolumn{5}{|c|}{ Histology of primary tumor } \\
\hline Invasive ductal & $118(80 \%)$ & $63(87 \%)$ & $25(90 \%)$ & $13(93 \%)$ \\
\hline Invasive lobular & $3(2 \%)$ & $5(7 \%)$ & - & - \\
\hline Mixed & $19(13 \%)$ & $4(6 \%)$ & $2(7 \%)$ & $1(7 \%)$ \\
\hline Other & $8(5 \%)$ & - & $1(3 \%)$ & - \\
\hline \multicolumn{5}{|l|}{ Molecular Subtypes } \\
\hline Luminal A & $70(47 \%)$ & $34(47 \%)$ & $5(17 \%)$ & $13(36 \%)$ \\
\hline Luminal B & $42(28 \%)$ & $21(29 \%)$ & $3(11 \%$ & $12(32 \%)$ \\
\hline HER-2 Positive & $15(10 \%)$ & $5(7 \%)$ & $12(43 \%)$ & 7 (19\%) \\
\hline Triple Negative & $15(10 \%)$ & $9(13 \%)$ & $8(29 \%)$ & $5(13 \%)$ \\
\hline Unknown & $6(5 \%)$ & $3(4 \%)$ & - & - \\
\hline
\end{tabular}

non-TNBC molecular subtype and treated with non-anthracycline adjuvant chemotherapy. Age at diagnosis, hormonal therapy, HER-2 positivity, administration of adjuvant chemotherapy, and menopausal status did not reach to statistical significance in regard to interval time to hepatic metastases (Table 3). Low grade (grade 1-2) tumors were associated with longer disease free interval to liver metastases by multivariate analysis.

\section{Overall Survival}

After the diagnosis of hepatic metastases, the median survival was calculated as 18 months. The longest median overall survival was seen in patients with isolated hepatic metastases (27 months). In non-isolated cases the longest median overall survival was in patients with accompanying bone metastasis ( 23 months), lung metastasis (15 months) and brain metastasis (13 months) (Table 4). As shown in Table 4, the survival after hepatic metastases between different molecular subtypes was significantly different with luminal B type being the most favorable molecular subtype by overall survival of 23 months, followed by luminal A type (22 months), Her-2 positive (19 months) and
TNBC (12 months) ( $\mathrm{p}=0.001)$ (Figure 1). Adjuvant chemotherapy regimens containing anthracycline were related with poor survival after the development of hepatic metastases however this was not statistically significant $(\mathrm{p}=0.3)$. This finding can be due to these patients' rather aggressive primary tumors. HER-2 positivity was significantly related with better overall survival. Metastasis in a time interval of less than 12 or 24 months was related with better survival after hepatic metastases (Table 4). Menopausal state was important in terms of overall survival with perimenopausal patients having the best overall survival with a median of 28 (17-38) months followed by premenopausal patients with 21 (17-24) months ( $\mathrm{p}=0.016)$.

In our patient population, 31 patients were given local hepatic treatments by means of surgery $(n=$ $8)$, radiofrequency ablation $(\mathrm{n}=9)$ chemoembolization $(n=6)$ and radio embolization $(n=8)$. When these patients were evaluated for molecular subtype, subtype of luminal A and B was seen 12 (39\%) and $12(39 \%)$ patients respectively. The remaining patients had her- 2 overexpression $(n=5$, $16 \%)$ and TNBC $(n=2,6 \%)$. Furthermore while majority of patients had isolated hepatic metastasis $(n=18,58 \%)$, the other patients had hepatic 
Table 3. Univariate and multivariate analysis of factors in time to hepatic metastases $(n=242)$

\begin{tabular}{|c|c|c|c|c|c|}
\hline Parameters (n) & Time (months) & $\mathbf{P}$ & HR & $\% 95 \mathrm{Cl}$ & $\mathbf{p}$ \\
\hline \multicolumn{6}{|l|}{ Age at Diagnosis } \\
\hline$<46(152)$ & $19(16-21)$ & 0.32 & & & \\
\hline$>46(154)$ & $15(12-17)$ & & & & \\
\hline Grade & & & 2.2 (grade 3 vs $1-2$ ) & $(1.6-3.1)$ & 0.0001 \\
\hline $1-2(93)$ & $46(36-51)$ & 0.0001 & & & \\
\hline $3(101)$ & $26(20-31)$ & & & & \\
\hline \multicolumn{6}{|l|}{ Adjuvant chemotherapy } \\
\hline Yes (221) & $41(36-45)$ & 0.88 & & & \\
\hline No (21) & $38(12-63)$ & & & & \\
\hline \multicolumn{6}{|l|}{ Adjuvant Radiotherapy } \\
\hline Yes (177) & $41(36-45)$ & 0.49 & & & \\
\hline No (63) & $39(32-45)$ & & & & \\
\hline \multicolumn{6}{|l|}{ Adjuvant Hormonotherapy } \\
\hline Yes (177) & $42(37-46)$ & 0.15 & & & \\
\hline No (65) & $36(27-44)$ & & & & \\
\hline \multicolumn{6}{|l|}{ Stage at diagnosis } \\
\hline $1-2(100)$ & $48(34-61)$ & 0.005 & & & \\
\hline $3(95)$ & $38(30-45)$ & & & & \\
\hline \multicolumn{6}{|l|}{ Her-2 Overexpression } \\
\hline Positive (66) & $31(18-43)$ & 0.42 & & & \\
\hline Negative (154) & $38(32-43)$ & & & & \\
\hline \multicolumn{6}{|l|}{ Adjuvant Chemotherapy } \\
\hline Adjuvant anthracycline (196) & $40(35-44)$ & 0.001 & & & \\
\hline Adjuvant not anthracycline (26) & $42(1-111)$ & & & & \\
\hline \multicolumn{6}{|l|}{ Histological Subtype } \\
\hline Other (202) & $42(37-46)$ & 0.004 & & & \\
\hline TNBC (33) & $23(17-28$ & & & & \\
\hline \multicolumn{6}{|l|}{ Menopausal state at diagnosis } \\
\hline Premenopausal (134) & $43(35-50)$ & 0.23 & & & \\
\hline Perimenopause (14) & $29(1-54)$ & & & & \\
\hline Postmenopausal (94) & $37(31-42)$ & & & & \\
\hline
\end{tabular}

with bone $(n=7,23 \%)$ and hepatic with lung $(n=6$, $19 \%)$ metastasis. Local treatment was related with better survival with 36 versus 18 months, and this difference reached to statistical significance $(\mathrm{p}=$ 0.004). In multivariate analysis, patients having early stage disease at diagnosis (stage 1-2 vs. stage 3) non-triple negative molecular subtype and presence of local treatment were found to have better prognostic factors (Table 4).

\section{DISCUSSION}

In this study, we presented one of the largest published series of breast cancer patients $(n=312)$ with liver metastases. We have identified and analyzed clinicopathological prognostic factors in this group of patients. It has been reported that nearly $30 \%$ of breast cancer patients will develop liver metastases along the duration of their disease. ${ }^{1-2}$ Liver metastases usually develop in the terminal stage of breast 
International Journal of Hematology and Oncology

Table 4. Univariate and multivariate analysis of prognostic factor after the development of hepatic metastases $(n=305)$

\begin{tabular}{|c|c|c|c|c|c|}
\hline Prognostic factors (n) & $\begin{array}{l}\text { Median OS (months) } \\
(95 \% \mathrm{Cl})\end{array}$ & $\mathbf{p}$ & HR & $\% 95 \mathrm{Cl}$ & $\mathbf{p}$ \\
\hline \multicolumn{6}{|l|}{ Age of diagnosis } \\
\hline$<46(163)$ & $21(17-24)$ & 0.21 & & & \\
\hline$>46(141)$ & $16(11-20)$ & & & & \\
\hline \multicolumn{6}{|l|}{ Grade } \\
\hline $1-2(105)$ & $22(19-24)$ & 0.55 & & & \\
\hline $3(134)$ & $15(11-18)$ & & & & \\
\hline \multicolumn{6}{|l|}{ Adjuvant chemotherapy } \\
\hline Yes (282) & $18(15-20)$ & 0.42 & & & \\
\hline No (23) & 27 (23-30) & & & & \\
\hline \multicolumn{6}{|l|}{ Adjuvant Radiotherapy } \\
\hline Yes (206) & $18(14-21)$ & 0.49 & & & \\
\hline No $(90)$ & $22(17-26)$ & & & & \\
\hline \multicolumn{6}{|l|}{ Stage at diagnose } \\
\hline $1-2(100)$ & $24(16-31)$ & 0.002 & 1.75 & $(1.2-2.5)$ & 0.003 \\
\hline $3(98)$ & $14(8-19)$ & & (stage 3 vs 1-2) & & \\
\hline \multicolumn{6}{|l|}{ Time to liver metastasis } \\
\hline$<12$ months (89) & $26(20-31)$ & 0.01 & & & \\
\hline >12months (216) & $17(13-20)$ & & & & \\
\hline \multicolumn{6}{|l|}{ Time to liver metastasis } \\
\hline$<24$ months (139) & $24(19-28)$ & 0.006 & & & \\
\hline >24months (166) & $16(12-19)$ & & & & \\
\hline \multicolumn{6}{|l|}{ Adjuvant hormonotherapy } \\
\hline Yes (210) & $21(17-24)$ & 0.34 & & & \\
\hline No (90) & $16(12-19)$ & & & & \\
\hline \multicolumn{6}{|l|}{ Her-2 } \\
\hline Positive (91) & $21(16-25)$ & 0.04 & & & \\
\hline Negative (192) & $18(13-22)$ & & & & \\
\hline \multicolumn{6}{|l|}{ Histological Subtype } \\
\hline Luminal A (127) & $22(15-28)$ & 0.002 & 1.76 & $(1.1-2.7)$ & 0.015 \\
\hline Luminal B (83) & $23(16-29)$ & & (TNBC vs other) & & \\
\hline Her-2 (46) & $19(10-27)$ & & & & \\
\hline TNBC (41) & $12(7-16)$ & & & & \\
\hline \multicolumn{6}{|l|}{ Adjuvant chemotherapy } \\
\hline Anthracycline+(229) & $17(13-20)$ & 0.3 & & & \\
\hline Anthracycline -(53) & $22(11-32)$ & & & & \\
\hline \multicolumn{6}{|c|}{ Menopausal state at diagnosis } \\
\hline Premenopausal (169) & $21(17-24)$ & 0.016 & & & \\
\hline Perimenopause (20) & $28(17-38)$ & & & & \\
\hline Postmenopausal (116) & $15(12-17)$ & & & & \\
\hline Local hepatic treatment & & & 0.52 & $(0.3-1.0)$ & 0.03 \\
\hline Yes (31) & $36(21-50)$ & 0.004 & & & \\
\hline No (282) & $18(14-21)$ & & & & \\
\hline \multicolumn{6}{|l|}{ Location of metastasis } \\
\hline Isolated hepatic & $27(9-44)$ & 0.011 & & & \\
\hline Hepatic with bone & $23(18-27)$ & & & & \\
\hline Hepatic with lung & $15(9-209$ & & & & \\
\hline Hepatic with brain & $13(3-22)$ & & & & \\
\hline
\end{tabular}




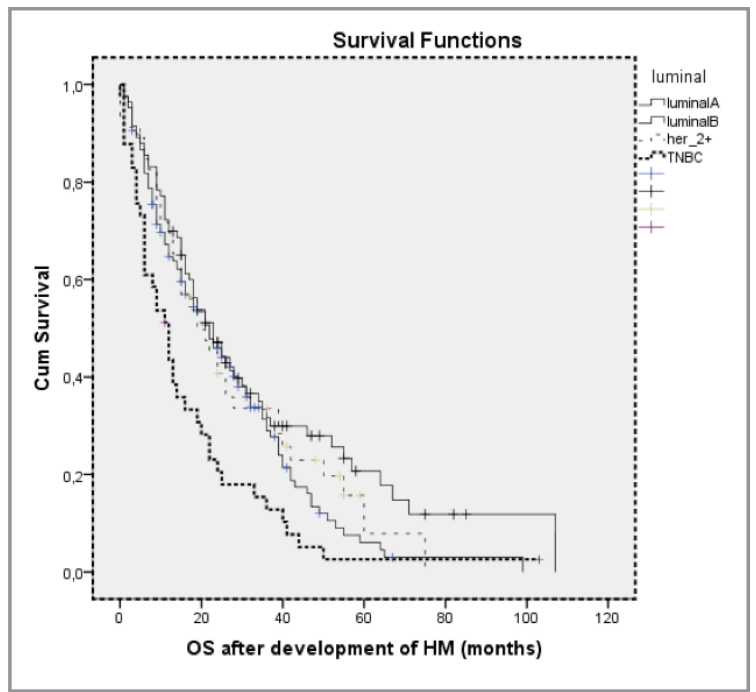

Figure 1. overall survival of molecular subtype of breast cancer with $\mathrm{HM}$

cancer, and are often accompanied by extrahepatic metastases. Isolated liver metastases are very rare $(4 \%-5 \%){ }^{10-11}$ In our study this was seen in 36 $(11 \%)$ patient. The presence of liver metastases has always been regarded as a poor prognostic factor with very short survival rates. This data however comes from older studies. Median survival was reported to be around 5 months and most patients in this study were presented at later stages with high tumor burden and poor hepatic reserves. ${ }^{4-6}$ In our patient population, overall survival after the diagnosis of liver metastases was 18 months which was in line with the results of more recent studies. ${ }^{12} \mathrm{We}$ revealed that early stage disease at diagnosis, non TNBC disease and presence of local hepatic treatment were long survival after hepatic metastasis by multivariate analysis (Table 4). However age at diagnosis, adjuvant chemotherapy, and adjuvant endocrine therapy were found to have no influence on survival in patients after the development of hepatic metastases.

In our study, the relative earlier appearance of hepatic metastases appeared to have a more favorable outcome that the development of hepatic metastases before 12 or 24 months following the primary diagnosis of breast cancer was significantly related with better overall survival compared to those where the hepatic deposits appeared at a later stage. Good prognosis with early metastasis was shown in a study by Qi Dong Ge, but in a study by
Wyld et al. ${ }^{13-14}$ metastasis free interval had no effect on survival. This can be attributed to all nodes that other systemic metastases were seen in patients with long disease free interval to liver metastases. We analyzed that lower grade (Grade 1-2) tumors were associated with longer disease free interval to liver metastases by multivariate analysis (Table 3 ).

New prognostic factors including molecular subtyping are being evaluated in clinical trials. Molecular subtyping may provide additional prognostic insight, but its clinical significance is yet to be established. ${ }^{15-17}$ It has been shown that patients with luminal A and B molecular subtype tumors have better overall survival. However in patients with hepatic metastases the survival difference among molecular subtypes may become less distinct. Indeed in a retrospective analysis from China, researchers found no difference in terms of survival between different molecular subtypes. ${ }^{11}$ On the other hand in our study, alongside with some other studies, the survival benefit of luminal A and B tumors persist even after the development of hepatic deposits. This difference can be attributed to the fact that our study has included a greater number of patients. Liver metastasis of breast cancer is heterogenic disease that median OS is longer in patient with accompanying bone and lymph nodes than that accompanies brain and lung metastases. Median OS in patients with bone metastasis was reported as 17 months in study of Zinser. In our study, on the other hand, median OS was calculated as 23 months in patients with bone metastatic group. In this group of patients a higher rate of luminal A and B (47\%, 27\% respectively) tumors were identified which may explain the improved survival.

TNBC subtypes tumors behave more aggressively and have worse survival compared other subtype which was supported by our study's findings. Indeed in our data the median survival in luminal A and $\mathrm{B}$ tumors were 22 and 23 months respectively while this was found to be 12 months in TNBC. Other than prognostic information, molecular subtyping can be a predictor of the metastatic site. Some studies showed that HER2-overexpressed subtype tumors spread to the liver relatively more often, while basal-like and TNBC subtypes metastasize to lung and brain. ${ }^{18}$ In our study TNBC ratio was $29 \%$ in patients with brain metastasis. Her-2 
overexpression was found to be an unfavorable prognostic factor in the literature. Although better results were reported with anti-her- 2 treatment in the literature, this effect was not statistically significant in some studies in patients with hepatic metastases. ${ }^{11,18}$ Our results have also shown that her-2 overexpression was not a favorable prognostic factor in our series. Prospective studies with larger samples may identify a causal relationship on this issue.

There is continuous improvement in the diagnostic modalities and therapeutic techniques which play an important role in the detection and treatment of liver lesions. Local treatment modalities have recently been introduced in metastatic breast cancer. Surgical resection, radiofrequency ablation (RFA), trans arterial chemoembolization (TACE), and stereotactic body radiation are among localized therapies. Local treatments of liver metastases in breast cancer patients were evaluated in some studies in the literature. Microscopically complete (R0) resection of metastases were found to be a favorable prognostic factor in multiple studies reported in the literature $^{19-20}$; local ablation studies produced similar results with five year survival rates reaching up to $40 \% .^{21}$ Performed in small prospective studies, it has been shown that RFA is also effective. In our study, we showed that local treatment (metastasectomy, RFA, radio embolization and TACE) provided statistically better survival according to both univariate and multivariate analysis (36 vs 18 months). It should be kept in mind as an adjunct to chemotherapy or as sole therapy in patients with no evidence of extrahepatic disease.

\section{Conclusion}

Prognosis of hepatic metastatic breast cancer is poor. Also the developments in systemic and targeted therapy and improved imaging modalities and therapeutic techniques have shown to provide survival benefit of this patient population. Local hepatic interventions are proven to be effective in isolated hepatic metastases patients. Classical and new prognostic factors like molecular subtyping appeared to have a better risk stratification in these patients. Prospective, randomized controlled trials are needed to evaluate the effect of these new techniques in this group of patients.

\section{REFERENCES}

1. Kiyotani K, Mushiroda T, Sasa M, et al. Impact of CYP2D6* 10 on recurrence-free survival in breast cancer patients receiving adjuvant tamoxifen therapy. Cancer science 99: 995-999, 2008.

2. Pentheroudakis G, Fountzilas G, Bafaloukos D, et al. Metastatic breast cancer with liver metastases: a registry analysis of clinicopathologic, management and outcome characteristics of 500 women. Breast Cancer Res Treat 97: 237-244, 2006.

3. Tampellini M, Berruti A, Gerbino A, et al. Relationship between CA 15-3 serum levels and disease extent in predicting overall survival of breast cancer patients with newly diagnosed metastatic disease. Br J Cancer 75: 698, 1997.

4. Hoe A, Royle G, Taylor I. Breast liver metastases-incidence, diagnosis and outcome. J R Soc Med 84: 714-716, 1991.

5. O'reilly SM, Richards MA, Rubens RD. Liver metastases from breast cancer: the relationship between clinical, biochemical and pathological features and survival. Eur J Cancer Clin Oncol 26: 574-577, 1990

6. Zinser JW, Hortobagyi GN, Buzdar AU, Smith TL, Fraschini G. Clinical course of breast cancer patients with liver metastases. J Clin Oncol 5: 773-782, 1987.

7. Kostov DV, Kobakov GL, Yankov DV. Prognostic factors related to surgical outcome of liver metastases of breast cancer. J Breast Cancer 16: 184-192, 2013.

8. Er O, Frye DK, Kau S-WC, et al. Clinical course of breast cancer patients with metastases limited to the liver treated with chemotherapy. The Cancer J 14: 62-68, 2008.

9. Atalay G, Biganzoli L, Renard F, et al. Clinical outcome of breast cancer patients with liver metastases alone in the anthracycline-taxane era: a retrospective analysis of two prospective, randomised metastatic breast cancer trials. Eur $\mathrm{J}$ Cancer 39: 2439-2449, 2003.

10. Elias D, Lasser P, Spielmann M, et al. Surgical and chemotherapeutic treatment of hepatic metastases from carcinoma of the breast. Surg Gynecol Obstet 172: 461-464, 1991

11. DiAz R, Santaballa A, Munarriz B, Calderero V. Hepatic resection in breast cancer metastases: should it be considered standard treatment? The Breast 13: 254-258, 2004.

12. Khanfir A, Lahiani F, Bouzguenda R, et al. Prognostic factors and survival in metastatic breast cancer: A single institution experience. Rep Prac Oncol Radiother 18: 127-132, 2013.

13. Ge Q-D, Lv N, Kong Y-N, et al. Clinical characteristics and survival analysis of breast cancer molecular subtypes with hepatic metastases. Asian Pac J Cancer Prev 13: 5081-5086, 2012.

14. Wyld L, Gutteridge E, Pinder S, et al. Prognostic factors for patients with hepatic metastases from breast cancer. $\mathrm{Br} J$ Cancer 89: 284-290, 2003.

15. Perou CM, Sørlie T, Eisen MB, et al. Molecular portraits of human breast tumours. Nature 406: 747-752, 2000.

16. Nielsen TO, Hsu FD, Jensen K, et al. Immunohistochemical and clinical characterization of the basal-like subtype of invasive breast carcinoma. Clin Cancer Res 10: 5367-5374, 2004. 
17. Engstrøm MJ, Opdahl S, Hagen Al, et al. Molecular subtypes, histopathological grade and survival in a historic cohort of breast cancer patients. Breast Cancer Res Treat 140: 463473, 2013.

18. Harrell JC, Prat A, Parker JS, et al. Genomic analysis identifies unique signatures predictive of brain, lung, and liver relapse. Breast Cancer Res Treat 132, 523-535, 2012.

19. Thelen A, Benckert C, Jonas S, et al. Liver resection for metastases from breast cancer. J Surg Oncol 97: 25-29, 2008.

20. Adam R, Aloia T, Krissat J, et al. Is liver resection justified for patients with hepatic metastases from breast cancer? Ann Surg 244: 897-908, 2006.

21. Bergenfeldt M, Jensen B, Skjoldbye B, Nielsen D. Liver resection and local ablation of breast cancer liver metastases-a systematic review. Eur J Surg Oncol (EJSO) 37: 549-557, 2011.

\section{Correspondence:}

Dr. Öztürk ATEŞ

Hacettepe Üniversitesi Kanser Enstitüsü

Tıbbi Onkoloji Bölümü

06100- Sihhiye

ANKARA / TURKEY

Tel: (+90-312) 3052939

Fax: (+90-312) 3242009

e-mail: dr.ozturkates@yahoo.com 